\title{
Article
}

\section{Tropospheric GOM at the Pic du Midi Observatory - correcting bias in denuder based observations}

Nicolas Marusczak, Jeroen E. Sonke, Xuewu Fu, and Martin Jiskra

Environ. Sci. Technol., Just Accepted Manuscript • Publication Date (Web): 14 Dec 2016

Downloaded from http://pubs.acs.org on December 14, 2016

\section{Just Accepted}

"Just Accepted" manuscripts have been peer-reviewed and accepted for publication. They are posted online prior to technical editing, formatting for publication and author proofing. The American Chemical Society provides "Just Accepted" as a free service to the research community to expedite the dissemination of scientific material as soon as possible after acceptance. "Just Accepted" manuscripts appear in full in PDF format accompanied by an HTML abstract. "Just Accepted" manuscripts have been fully peer reviewed, but should not be considered the official version of record. They are accessible to all readers and citable by the Digital Object Identifier (DOI®). "Just Accepted" is an optional service offered to authors. Therefore, the "Just Accepted" Web site may not include all articles that will be published in the journal. After a manuscript is technically edited and formatted, it will be removed from the "Just Accepted" Web site and published as an ASAP article. Note that technical editing may introduce minor changes to the manuscript text and/or graphics which could affect content, and all legal disclaimers and ethical guidelines that apply to the journal pertain. ACS cannot be held responsible for errors or consequences arising from the use of information contained in these "Just Accepted" manuscripts.

This document is the unedited Author's version of a Submitted Work that was subsequently accepted for publication in Environmental Science \& Technology, copyright (@ American Chemical Society after peer review. To access the final edited and published work see: https://pubs.acs.org/doi/10.1021/acs.est.6b04999 
1 Tropospheric GOM at the Pic du Midi Observatory - correcting bias in denuder based observations

2

3

$$
\text { Nicolas Marusczak }{ }^{\dagger} \text {, Jeroen E. Sonke }{ }^{\dagger, *}, \text { Xuewu Fu }^{+, \neq}, \text {and Martin Jiskra }^{\dagger}
$$

${ }^{\dagger}$ Observatoire Midi-Pyrénées, Laboratoire Géosciences Environnement Toulouse, CNRS/IRD/Université de Toulouse, 14, avenue Édouard Belin, 31400 Toulouse, France

${ }^{*}$ Present address: State Key Laboratory of Environmental Geochemistry, Institute of Geochemistry, Chinese Academy of Sciences, Guiyang, China.

*Corresponding Author: Tel. +33 561332606, Fax: +33 561332560, Email : sonke@get.obs-mip.fr

Abstract

Gaseous elemental mercury (GEM, $\mathrm{Hg}$ ) emissions are transformed to divalent reactive $\mathrm{Hg}$ (RM) forms throughout the troposphere and stratosphere. RM is often operationally quantified as the sum of particle bound $\mathrm{Hg}(\mathrm{PBM})$ and gaseous oxidized $\mathrm{Hg}(\mathrm{GOM})$. The measurement of GOM and PBM is challenging and under mounting criticism. Here we intercompare six months of automated GOM and PBM measurements using a $\operatorname{Tekran}^{\circledR}(\mathrm{TK}) \mathrm{KCl}$-coated denuder and quartz regenerable particulate filter method $\left(\mathrm{GOM}_{\mathrm{TK}}, \mathrm{PBM}_{\mathrm{TK}}\right.$, and $\mathrm{RM}_{\mathrm{TK}}$ ) with $\mathrm{RM}_{\mathrm{CEM}}$ collected on cation exchange membranes (CEMs) at the high altitude Pic du Midi Observatory. We find that $\mathrm{RM}_{\mathrm{TK}}$ is systematically lower by a factor of 1.3 than $\mathrm{RM}_{\mathrm{CEM}}$. We observe a significant relationship between $\mathrm{GOM}_{\mathrm{TK}}$ (but not $\mathrm{PBM}_{\mathrm{TK}}$ ) and Tekran $^{\circledR}$ flush $_{\mathrm{TK}}$ blanks suggesting significant loss (32\%) of labile $\mathrm{GOM}_{\mathrm{TK}}$ from the denuder or inlet. Adding the flush ${ }_{\mathrm{TK}}$ blank to $\mathrm{RM}_{\mathrm{TK}}$ results in good agreement with $\mathrm{RM}_{\mathrm{CEM}}$ (slope=1.01, $\mathrm{r}^{2}=0.90$ ) suggesting we can correct bias in $\mathrm{RM}_{\mathrm{TK}}$ and $\mathrm{GOM}_{\mathrm{TK}}$. We provide a bias corrected $(*)$ Pic du Midi dataset for 2012-2014 that shows GOM* and RM* levels in dry free tropospheric air of $198 \pm 57$ and $229 \pm 58 \mathrm{pg} \mathrm{m}^{-3}$ which agree well with in-flight observed RM and with model based GOM and RM estimates. 
24

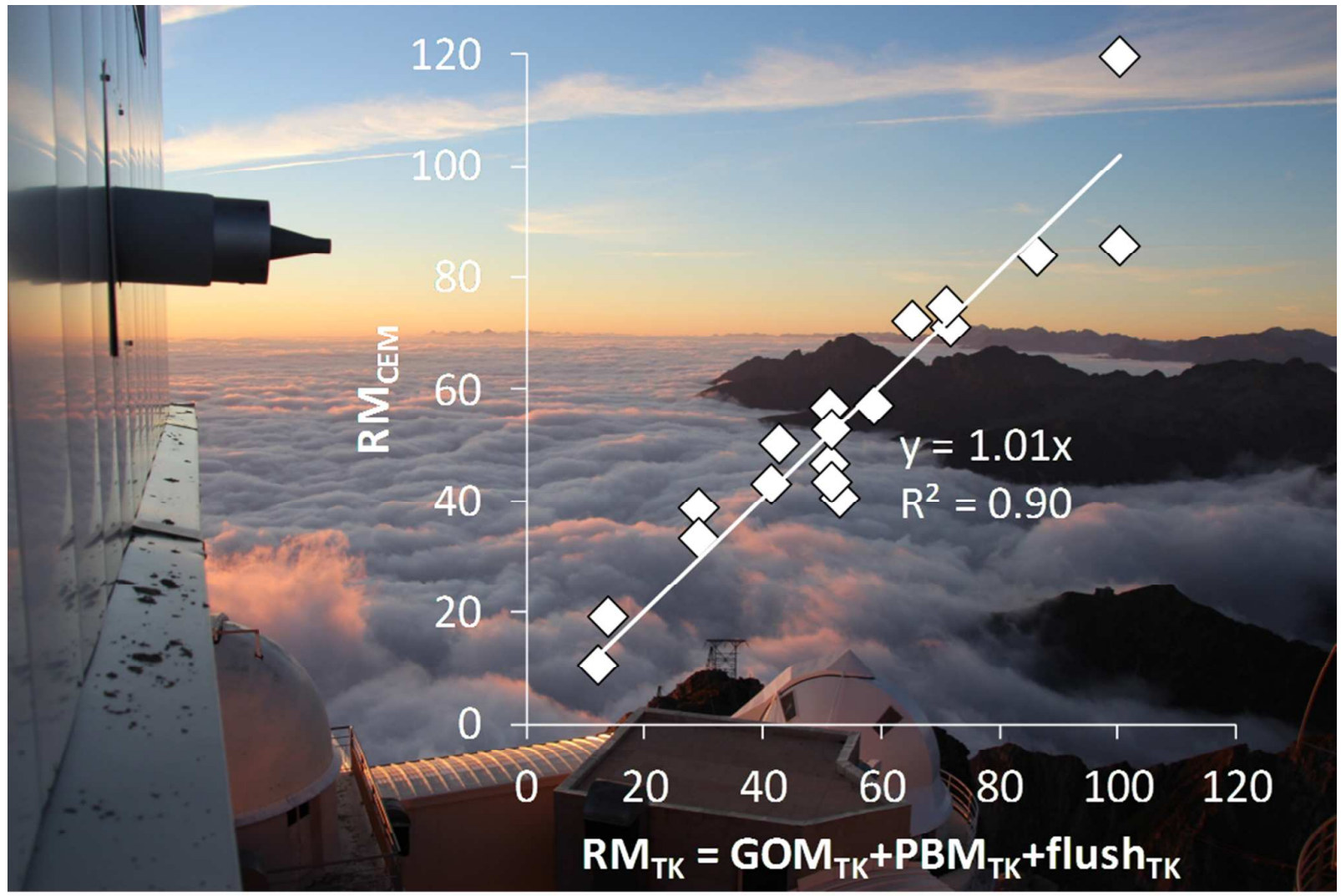

Image credit: Jeroen Sonke 


\section{Introduction:}

Mercury $(\mathrm{Hg})$ is a pollutant of global concern with anthropogenic emissions outweighing natural volcanic emissions by an order of magnitude [1]. Due to its long atmospheric lifetime, on the order of 4 to 12 months, atmospheric circulation carries gaseous elemental Hg (GEM) emissions across the globe and into the upper troposphere and stratosphere [2-4]. Apart from wet deposition, four operationally defined forms of atmospheric $\mathrm{Hg}$ have been studied and/or monitored: GEM, gaseous oxidized mercury (GOM), particulate bound mercury (PBM), or divalent reactive $\mathrm{Hg}(\mathrm{RM})$, which is the sum of GOM and PBM. In the lower troposphere GOM and PBM are rapidly (days-weeks) transferred to the Earth's surface via wet (i.e. rain and snow fall) and dry deposition (Lindberg et al., 2007). In the upper troposphere and stratosphere, GOM and PBM have longer lifetimes on the order of weeks to months [5]. GEM emissions can be transformed to RM by oxidation, but the exact nature of the oxidant(s) $\left(\mathrm{O}_{3}, \mathrm{OH}\right.$ and $\left.\mathrm{Br}, \mathrm{NO}_{\mathrm{x}}\right)$ and the produced oxidized forms of $\mathrm{Hg}\left(\mathrm{HgCl}_{2}, \mathrm{HgBr}_{2}, \mathrm{HgO}, \mathrm{HgNO}_{3}, \mathrm{HgSO}_{4}, \mathrm{PBM}\right)$ are topics of debate [6-10].

Operational quantification of GOM, PBM, or RM has been performed by a variety of techniques including sequential oxidizing solution traps (Ontario-Hydro method)[11], mist chambers [12], $\mathrm{KCl}$-coated tubular and annular denuders [13, 14], cation exchange membranes [15-17], indirect difference-based RM (as total mercury (TM) - GEM[18-20]), and chemical ionization mass spectrometry [21]. KCl-coated denuders and regenerable quartz filters have been integrated in automated atmospheric $\mathrm{Hg}$ speciation analyzers [13]. The automated speciation systems have permitted great advances in our understanding of atmospheric $\mathrm{Hg}$ dynamics, and have become the workhorse of modern $\mathrm{Hg}$ speciation monitoring networks such as AMNet, GMOS and CAMnet [22-24].

Previous research has identified analytical issues with $\mathrm{KCl}$-coated denuder based GOM sampling. Interferences with relative humidity and ambient levels of ozone affect $\mathrm{GOM}$ adsorption to $\mathrm{KCl}$ [25-28]. The RAMIX project extensively investigated different GOM detection methods $[29,30]$. It was observed that cation exchange membranes (CEM) collect between 1.3 and 3.7 times more $\mathrm{Hg}$ than $\mathrm{KCl}$-denuders in laboratory and field experiments [16, 26]. Criticism on GOM (and PBM) sampling with denuders is mounting and emphasizes the need for better calibration and identification methods for GOM and renewed 
54 development of alternative methods [31]. The observed inefficiencies of GOM collection by $\mathrm{KCl}$-coated 55 denuders illustrate the operational and qualitative nature of the method. Given the wealth of observations 56 made with automated denuder based $\mathrm{Hg}$ speciation systems over the past decade it is also of interest to 57 develop a GOM and/or RM loss correction method and, where possible, re-evaluate datasets acquired over the past 15 years.

In this study we compare manual CEM sampling of RM to automated $\mathrm{KCl}$-denuder and quartz filter sampling of GOM and PBM using a Tekran $^{\circledR} 1130 / 1135 / 2537 \mathrm{~B}$ system at the high altitude Pic du Midi Observatory (2877m asl, French Pyrenees). In addition, we discuss remarkable, but recurring, observations on denuder flush blanks in relation to GOM levels. The ensemble of automated and manual RM observations allows us to propose a RM and GOM loss correction method for the Pic du Midi dataset.

2. Methods:

\subsection{Sampling Site}

67 The Pic du Midi Observatory (PDM, 42.937 N, 0.142 E, $2877 \mathrm{~m}$ a.s.l) is a high-altitude site situated on the northern edge of the Pyrenees mountains (France). PDM typically receives free tropospheric air masses from the North Atlantic Ocean and continental Europe. PDM has no nearby anthropogenic emission point sources, but does receive polluted boundary layer air masses from nearby valleys during daytime upslope winds [32, $7133]$.

\subsection{Automated Hg speciation measurements}

74 From $18^{\text {th }}$ November 2011 to $31^{\text {th }}$ December 2014, GEM $\mathrm{TK}_{\mathrm{TK}}, \mathrm{GOM}_{\mathrm{TK}}$ and $\mathrm{PBM}_{\mathrm{TK}}$ were continuously measured at 75 The Pic du Midi observatory, using a Hg speciation unit (1130/1135) coupled to a 2537B analyser (Tekran 76 Inc., Canada). All Tekran ${ }^{\circledast}$ 2537B/1130/1135 components are housed in-doors at PDM due to high lightning 77 risk in summer and abundant ice riming the rest of the year. Ambient air was provided to the Tekran ${ }^{\circledR}$ unit 78 using the Tekran ${ }^{\oplus} 1104$ Teflon coated, heated $\left(50^{\circ} \mathrm{C}\right)$ manifold, operating at $100 \mathrm{~L} \mathrm{~min}^{-1}$. $\mathrm{GOM}_{\mathrm{TK}}, \mathrm{PBM}_{\mathrm{TK}}$ and $79 \mathrm{GEM}_{\mathrm{TK}}$ are sampled through $\mathrm{KCl}$-coated denuder, quartz fiber filter and dual gold cartridges respectively. 
GEM $_{\text {TK }}$ was collected every 5 minutes at $0.7 \mathrm{~L} \mathrm{~min}^{-1}$ and $\mathrm{GOM}_{\mathrm{TK}}$ and $\mathrm{PBM}_{\mathrm{TK}}$ are collected at one hour intervals at a flow rate of $5.6 \mathrm{~L} \mathrm{~min}^{-1}$ (flow rates relative to standard conditions, i.e. $273.14^{\circ} \mathrm{K}$ and $1013 \mathrm{hPa}$ ). Detailed standard operating procedures (SOPs), based on Tekran ${ }^{\circledR}$ manuals and consistent with AMNet and GMOS SOPs, QA/QC and results for the period 18/11/2011 to 17/11/2012 have been presented elsewhere [33]. In this study $\mathrm{GOM}_{\mathrm{TK}}$ and $\mathrm{PBM}_{\mathrm{TK}}$ are calculated without subtraction of the flush blank in order to evaluate the behaviour of the flush blank itself. The full 2012-2014 PDM dataset is provided in the supporting information (SI-1). A calibration error for the year 2012 was corrected leading to lower GEM values than in [REF] (1.54 instead of $1.86 \mathrm{ng} \mathrm{m}^{-3}$ ), and consistent annual mean GEM values for 2012, 2013, 2014 of 1.54, 1.54, and 1.53 ng $\mathrm{m}^{-3}$.

89

\subsection{CEM deployment and analysis}

Based on the methods published by Huang et al., (2013), we used polyethersulfone CEMs, 47 and/or 90mm, $0.45 \mu \mathrm{m}$ pore size, Sterlitech Corporation and Millipore brands), to sample RM. Ambient atmospheric air was pumped at $1 \mathrm{~L} \mathrm{~min}$ (47mm filters) or $4 \mathrm{~L} \mathrm{~min}^{-1}$ (90mm filters) from the same ambient air flow used by the Tekran $^{\circledast}$ system and provided via two of the six side ports on the Tekran ${ }^{\circledast} 1104$ manifold. Teflon filter holders (Savillex ${ }^{\circledast}$ ) and $10 \mathrm{~cm}$ long $1 / 4^{\prime \prime}$ Teflon tubing were used to sample RM on CEMs as close as possible to the undisturbed ambient air flow as possible. We assume that RM did not degrade during the 63 milliseconds it took from the manifold flow to the CEM. A ball flow meter (Fisher Scientific), membrane pump (KNF), and gas volume meter (JHC) sampling train was used to regulate and quantify the total volume sampled, and was calibrated before and after each sampling period using a Bios Defender calibration unit. Teflon filter holders and tubing were acid washed, rinsed with MilliQ water, and double zip-lock bagged in a class-100 laminar flow hood before field deployment. Following sampling, CEMs were refrigerated $\left(4^{\circ} \mathrm{C}\right)$ and kept in the dark until analysis. To collect a sufficient quantity of RM, CEMs were deployed over 14 days.

In the laboratory, RM was extracted from each CEM in $10 \mathrm{ml} 20$ vol.\% inverse aqua regia $\left(2: 1 \mathrm{HNO}_{3}\right.$ : $\mathrm{HCl}$, both double-distilled) in closed Teflon beakers for 12 hours at $120^{\circ} \mathrm{C}$. $\mathrm{Hg}$ concentrations of the extracts were determined by cold vapor atomic fluorescence spectrometry (CV-AFS) using a Brooks Rand Model III 
106 AFS detector. The CV-AFS calibration range was 0-100 pg, made using dilutions of the NIST 3133 certified 107 reference material (CRM), and had a limit of detection (LOD, 3o of blanks) of 5.0 pg Hg. The CRM NRC ORMS-

1084 (certified at $26.2 \mathrm{ng} \mathrm{L}^{-1}$ ) was analysed multiple times during each CV-AFS session with good results and a

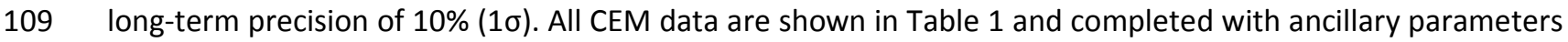
110 in the supporting information (SI-2).

111

112

\subsection{CEM Hg blanks}

Extraction blanks of untreated CEMs were determined using the protocol describe in section 2.3. We have not attempted to decontaminate CEMs in acidic solutions, in fear of compromising the polyethersulfone structure and functional groups. Reagent blanks were $12 \pm 14 \mathrm{pg}$ of $\mathrm{Hg}(1 \sigma, n=5)$. Sterlitech 47 and 90 mm CEM blanks were on average $464 \pm 85$ pg of $\mathrm{Hg}(1 \sigma, n=9)$, and $3179 \mathrm{pg} \pm 564$ of $\mathrm{Hg}(1 \sigma, n=6)$ which can be considered as very elevated. Millipore 47 and $90 \mathrm{~mm} \mathrm{CEM}$ blanks were $60 \pm 13 \mathrm{pg}$ of $\mathrm{Hg}(1 \sigma$, $n=12)$, and $157 \mathrm{pg} \pm 23 \mathrm{pg}$ of $\mathrm{Hg}(1 \sigma, n=19)$. These results indicate that untreated CEM blanks scale with

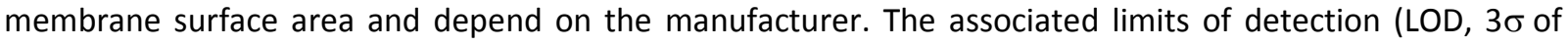
blank) are 255, 1700, 39 and 69 pg Hg respectively. Typical amounts of $\mathrm{Hg}$ collected during bi-weekly sampling periods range from 1.32 to $10.3 \mathrm{ng} \mathrm{Hg}$ (Sterlitech) and from 0.49 to $2.6 \mathrm{ng} \mathrm{Hg}$ (Millipore) and were above the methods LOD. Because of the lower blanks, we switched halfway this study from Sterlitech to the cleaner Millipore membranes. This permitted us to explore daily sampling of RM, using the Millipore $90 \mathrm{~mm}$ filters with the 157 pg blank and 69pg LOD. Five daily samples were collected from 1/12/2014 to 6/12/2014 which ranged from 300 to $1200 \mathrm{pg} \mathrm{Hg}$. In the discussion below the corresponding filter blanks were subtracted for all samples.

\section{Results and discussion}

CEMs have been applied to manual trace level GOM sampling since the 1990s [17]. CEMs have recently regained interest as KCL-denuder based automated GOM collection is sensitive to bias [16, 25, 26]. Huang et al. performed QA/QC testing on GOM collection efficiency by $47 \mathrm{~mm}, 0.45 \mu \mathrm{m}$ CEMs using controlled GOM 
132 dosing by permeation sources. They observed no breakthrough of GOM from CEMs under a flow of $1 \mathrm{~L}$ min-

133 1, deployed for 8 h (experiments), or up to 7 days (outdoors ambient air). They also did not observe GEM

134 capture on CEMs at experimental GEM levels $<13 \mathrm{ng} \mathrm{m}^{-3}$. Controlled GOM dosing of high levels (150-3000 pg

$135 \mathrm{~m}^{-3}$ ) of gaseous and $\mathrm{HgBr}_{2}, \mathrm{HgCl}_{2}$, and $\mathrm{HgO}$ revealed 1.6, 2.4 and 3.7 times higher collection efficiency on

136 CEMs compared to automated $\mathrm{KCl}$-coated denuders. In this study we deployed $47 \mathrm{~mm}, 0.45 \mu \mathrm{m}$ CEMs at $1 \mathrm{~L}$

$137 \mathrm{~min}^{-1}$, similar to Huang et al., in order to avoid breakthrough issues. We scaled up the flow rate to $4 \mathrm{~L} \mathrm{~min}^{-1}$ 138 when using the larger $90 \mathrm{~mm} 0.45 \mu \mathrm{m}$ CEMs.

Table 1 and SI-2 summarize CEM deployment conditions, $\mathrm{RM}_{\mathrm{CEM}}$ amounts ( $\mathrm{pg} \mathrm{Hg}$ ) and $\mathrm{RM}_{\mathrm{CEM}}$ concentrations $\left(\mathrm{pg} \mathrm{m}^{-3}\right)$, corresponding mean $\mathrm{GEM}_{T \mathrm{TK}}, \mathrm{GOM}_{\mathrm{TK}}, \mathrm{PBM}_{\mathrm{TK}}$, the three consecutive flush $\mathrm{TK}_{\mathrm{TK}}$ blanks, and pyrolizer ${ }_{\text {TK }}$ blank measured with the Tekran $^{\circledR}$ system, and corresponding meteorology, $\mathrm{CO}$ and $\mathrm{O} 3$ from the PAES database [34]. Figure $1 \mathrm{~d}$ shows that $\mathrm{RM}_{\mathrm{CEM}}$ collected on the CEMs is $1.26 \mathrm{x}$ higher $\left(r^{2}=0.85\right)$ than $\mathrm{RM}_{\mathrm{TK}}$ concentrations from the automated $\mathrm{Tekran}^{\circledR}$ system, calculated as the sum of $\mathrm{KCl}$-coated denuder based $\mathrm{GOM}_{\mathrm{TK}}$ and quartz filter based $\mathrm{PBM}_{\mathrm{TK}}$ concentrations. This result is similar to field deployment of CEMs at three sites by Huang et al. who found $1.5 \pm 0.4\left(1 \sigma, r^{2}=0.53\right)$ times higher RM on CEMs than automated denuders and RPFs. A substantial fraction of $\mathrm{RM}_{\mathrm{TK}}$ thus appears to be lost from the automated $\mathrm{GOM}_{\mathrm{TK}}$ and $\mathrm{PBM}_{\mathrm{TK}}$ collection system. quantification sequence. Figure $1 \mathrm{a}$, which summarizes three years of data, shows a significant correlation

152 (slope=0.48, $\mathrm{r}^{2}=0.62$ ) between the amount of $\mathrm{Hg}$ released during the three 5 -min flush cycles $\left(\right.$ flush $\left._{\text {TK1-3 }}\right)$ and 153 the amount subsequently detected as $\mathrm{GOM}_{\mathrm{TK}}$ during the three 5-min denuder desorption cycles. A similar 154 correlation is obtained for bi-weekly integrated $\mathrm{GOM}_{\mathrm{TK}}$ and flush $\mathrm{TK}_{\mathrm{TK}}$ shown in Figure 1a (slope of 0.46 , $\left.155 r^{2}=0.83\right)$. Table 2 illustrates the sequence of events in detail for a 1-hour $\mathrm{Hg}$ speciation analysis periods that 156 was part of high GOM event\#7. The data correspond to the maximum GOM concentration of $167 \mathrm{pg} \mathrm{m}^{-3}$ 157 detected during a long-lived (12h) GOM event that was discussed in detail elsewhere [33]. GOM event \#7 is a 
158 typical summer time phenomenon where upper free tropospheric air descends onto the PDM. Table 2

159 illustrates how the three flush ${ }_{T K}$ cycles, which follow a full hour of automated GEM $_{T K}$ analysis (last two cycles 160 only shown) and parallel GOM $\mathrm{TK}_{\mathrm{TK}}$ and $\mathrm{PBM}_{\mathrm{TK}}$ sampling, produce elevated flush $_{\mathrm{TK}}$ readings of $27,21,11 \mathrm{pg} \mathrm{m}^{-3}$. Hg monitoring networks that use Tekran ${ }^{\circledR}$ systems use standard operating procedures (SOPs) that calculate GOM and PBM as the sum of their respective three desorption cycles minus three times the value of the third flush cycle. The initial two flush cycles are aimed at purging residual ambient air from the system's dead volume, so that the third flush cycle is thought to represent the instrumental blank during denuder and RPF heating cycles. With a dead volume of approximately $1 \mathrm{~L}$, and ambient GEM $\mathrm{TK}_{\mathrm{TK}}$ levels of 1.5 $\mathrm{ng} \mathrm{m}{ }^{-3}$, the amount of $\mathrm{Hg}$ detected during the first flush cycle should be on the order of $1.5 \mathrm{pg} \mathrm{Hg}$, and shown in the first flush $\mathrm{TK}_{1}$ cycle as $5 \mathrm{pg} \mathrm{m}^{-3}$ (taking into account relevant scaling factors). The total amount of $\mathrm{Hg}$ detected during the three flush cycles (flush $\mathrm{TK}_{\mathrm{T}}=27+21+11=59 \mathrm{pg} \mathrm{m}^{-3}$ ) is one order larger than such a dead volume effect. In order to understand which of the Tekran ${ }^{\circledR}$ components (i.e. inlet+denuder, RPF or pyrolizer) releases $\mathrm{Hg}$ during the flush cycles we examined potential correlations between flush $\mathrm{TK}_{\mathrm{T}}$ and $\mathrm{PBM}_{\mathrm{TK}}$

$171\left(r^{2}=0.01\right)$, pyrolizer cycle $\mathrm{Hg}, \mathrm{RH}, \mathrm{CO}, \mathrm{O}_{3}$, air temperature etc. yet found none (Figure $\left.1 \mathrm{c}\right)$. The observation 172 that flush ${ }_{\mathrm{TK}}$ does not correlate with $\mathrm{PBM}_{\mathrm{TK}}$ is also illustrated in Table 2 for a $2^{\text {nd }} \mathrm{Hg}$ speciation period that represents the maximum $\mathrm{PBM}_{\mathrm{TK}}$ concentration detected during PBM event \#12 discussed in detail by Fu et al., (2016). PBM event\#12 is a typical winter time phenomena where cold middle to upper free tropospheric 175 air with elevated PBM (here $94 \mathrm{pg} \mathrm{m}^{-3}$ ) is regularly observed at PDM. The total amount of $\mathrm{Hg}$ detected during 176 the three flush cycles $\left(\mathrm{Hg}_{\text {flush }}=3.2+1.9+0=5.1 \mathrm{pg} \mathrm{m}^{-3}\right)$ is now similar to dead volume and regular instrumental 177 blank levels. We therefore strongly suspect that the elevated flush $\mathrm{TK}_{\mathrm{T}}$ levels are caused by $\mathrm{Hg}$ loss from the $178 \mathrm{KCl}$-coated denuder and/or heated inlet and not the RPF or pyrolizer components. amount of $\mathrm{GOM}_{\mathrm{TK}}$ detected during subsequent denuder heating cycles leads to the question whether we can 181 correct existing atmospheric $\mathrm{Hg}$ speciation datasets by adding flush $\mathrm{TK}_{\mathrm{K}}$ to $\mathrm{GOM}_{\mathrm{TK}}$. In order to evaluate this we need to understand whether GOM is only lost during the three 5-min flush cycles, when Hg-free air provided by the Tekran ${ }^{\circledast}$ instrument flushes the inlet glassware, denuder, RPF and transfer tubing, or whether it is lost 
184 continuously during the entire 1 hour sampling period. In Figure $1 \mathrm{e}$ we compare the sum of $185 \mathrm{GOM}_{\mathrm{TK}}+\mathrm{PBM}_{\mathrm{TK}}+\mathrm{flush}_{\mathrm{TK}}$ to $\mathrm{RM}_{\mathrm{CEM}}$ and observed an excellent correlation (slope is $1.01, \mathrm{r}^{2}=0.90$ ) that is 186 indicative of mass balance within the combined analytical uncertainties. The mass balance suggests that 187 most likely GOM is not lost continuously during sampling, but occurs specifically during the introduction of 188 Hg-free air during the flush cycles. We will now explore the use of Tekran ${ }^{\circledR}$ system PBM $_{T K}$ observations to 189 approximate $\mathrm{GOM}_{\mathrm{CEM}}$ collected onto the CEMs by difference: $\mathrm{GOM}_{\mathrm{CEM}}=\mathrm{RM}_{\mathrm{CEM}}-\mathrm{PBM}_{\mathrm{TK}}$. In doing so we can estimate a GOM loss factor from $\mathrm{KCl}$-coated denuder by comparing $\mathrm{GOM}_{\mathrm{CEM}}$ to $\mathrm{GOM}_{\mathrm{TK}}$. Figure $1 \mathrm{f}$ shows that $\mathrm{GOM}_{\mathrm{CEM}}$ is consistently higher by a factor of 1.56 than $\mathrm{GOM}_{\mathrm{TK}}$ throughout the dataset, and regardless of filter type, sampling flow rate, weather conditions, air mass origin or sampling duration ( 1 day vs 2 weeks). RAMIX project results showed that experimental $\mathrm{HgBr}_{2}$ retention was 1.6 and 2.0 times higher on CEMs than on automated denuders and a RM difference method, which may suggest that GOM at the PDM is predominantly in the $\mathrm{HgBr}_{2}$ form[16, 35].

Figure 1a also shows that there is substantial variability in the ratio of flush $\mathrm{TK}_{\mathrm{T}}$ to $\mathrm{GOM}_{\mathrm{TK}}$ for each 2hour period. At times flush ${ }_{\mathrm{TK}}$ represents only $20 \%$ of $\mathrm{GOM}_{\mathrm{TK}}$ and at other times up to $200 \%$, i.e. more $\mathrm{GOM}$ is lost than detected. Most likely this variability relates to the retention efficiency of different GOM compounds under the influence of different ambient air components such as $\mathrm{O}_{3}$ and $\mathrm{RH}$ that are known to affect GOM retention on denuders $[25,26]$. Using our parallel bi-weekly CEM and Tekran $^{\circledR}$ observations we have explored whether the flush ${ }_{T K} / \mathrm{GOM}_{T K}$, flush ${ }_{T K} / \mathrm{GOM}_{\mathrm{CEM}}$ or $\mathrm{GOM}_{\mathrm{TK}} / \mathrm{GOM}_{\mathrm{CEM}}$ ratios correlate with $\mathrm{RH}, \mathrm{CO}$, $\mathrm{O}_{3}$, GEM etc., but without succes. Most likely the longer 14-day CEM sampling period averages out variable $\mathrm{GOM}_{\mathrm{TK}}$ loss conditions and trends are lost. We have further attempted to document more variable $\mathrm{GOM}_{\mathrm{CEM}} / \mathrm{GOM}_{\mathrm{TK}}$ denuder loss factors and correlate these with flush $\mathrm{TK}_{\mathrm{TK}} / \mathrm{GOM}_{\mathrm{TK}}$ ratios by sampling $\mathrm{RM}_{\mathrm{CEM}}$ at a daily frequency (and higher flow rate of $13 \mathrm{~L} \mathrm{~min}^{-1}$ ) during the short period from 1/12/2016 to 5/12/2016. However, similar $\mathrm{RM}_{\mathrm{TK}}$ and $\mathrm{GOM}_{\mathrm{TK}}$ loss factors of 1.3 and 1.8 were observed as compared to bi-weekly

207 integrated loss factors. Longer campaigns deploying even higher time resolution for CEMs (12h or less) will be required to study variations in $\mathrm{GOM}_{\mathrm{TK}}$ loss due to $\mathrm{GOM}$ forms or different control factors. 


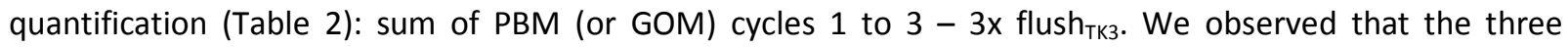

212 consecutive flush cycles 1-3 are also inter-correlated, e.g. flush $\mathrm{TK} 3=0.06 \times$ flush $_{\text {TK1-3 }}\left(r^{2}=0.63\right.$; see SI-2). This suggests that flush ${ }_{\text {Тк } 3}$ does not represent the instrument blank but is controlled by GOM loss at PDM. Since flush $_{\mathrm{TK} 3}$ is heavily impacted by $\mathrm{GOM}_{\mathrm{TK}}$ loss the SOPs regularly overestimate the true $\mathrm{PBM}_{\mathrm{TK}}$ and $\mathrm{GOM}_{\mathrm{TK}}$ blanks and thereby further bias $\mathrm{PBM}_{\mathrm{TK}}$ and $\mathrm{GOM}_{\mathrm{TK}}$ to lower values. For the PDM dataset (SI-2) we therefore do not further correct the integrated $\mathrm{PBM}_{\mathrm{TK}}$ and $\mathrm{GOM}_{\mathrm{TK}}$ cycles, i.e. we do not correct for blanks and propose the following equations for $\mathrm{GOM}_{\mathrm{TK}}$ * and $\mathrm{PBM}_{\mathrm{TK}} *$ quantification:

$\mathrm{GOM}_{\mathrm{TK}} *=\sum \mathrm{GOM}_{\mathrm{TK} 1-3}+\sum$ flush $_{\mathrm{TK} 1-3}$

$\mathrm{PBM}_{\mathrm{TK}} *=\sum \mathrm{PBM}_{\mathrm{TK} 1-3}$

In SI-2 we make available both the uncorrected and bias corrected (indicated by *, i.e $\mathrm{GOM}_{\mathrm{TK}}{ }^{*}, \mathrm{PBM}_{\mathrm{TK}}{ }^{*}$, $\left.\mathrm{GEM}_{\mathrm{TK}}{ }^{*}, \mathrm{RM}_{\mathrm{TK}}{ }^{*}\right)$ PDM Hg speciation dataset for the period 2011-2014, including ancillary parameters.

\section{Implications for atmospheric $\mathrm{Hg}$ science}

224 Our observation at PDM that denuder-based $\mathrm{GOM}_{\mathrm{TK}}$ is approximately 1.6-fold underestimated may have 225 important ramifications for global $\mathrm{Hg}$ cycling models that adjust GEM oxidation rates and mechanisms to fit 226 denuder-based $\mathrm{GOM}_{\mathrm{TK}}$ observations. Here we discuss PDM observations in comparison to other high227 elevation sites, aircraft campaigns, and model results. Manual denuder-based GOM and/or PBM collection 228 and quantification have been used by two aircraft studies [18, 36]. Continuous in-flight RM detection is more 229 regularly performed using the Dual-channel Oxidized Hg System (DOhGS) method [9, 10, 18-20]. The DOhGS 230 is a difference method, analysing total $\mathrm{Hg}$ (TM, by a pyrolizer) and GEM simultaneously on two parallel 231 Tekran ${ }^{\circledast} 2537$ analyzers, with a RM (= TM - GEM) LOD of 0.05 to $0.28 \mathrm{ng} \mathrm{m}^{-3}$, sufficient for free tropospheric 232 or stratospheric observations. Lyman and Jaffe (2011) reported elevated RM from 80 to $600 \mathrm{pg} \mathrm{m}^{-3}$ during an 233 NCAR C-130 flight in a stratosphere-influenced air mass intersected at 6-7km altitude over the USA. Upper 234 tropospheric air masses during the same flight were documented to contain $<49$ (LOD) to $220 \mathrm{ng} \mathrm{m}^{-3}$ of RM. 
235 Subsequent deployment of the DOhGS during 19 NOMADSS flights over the central and eastern USA[10] 236 documented RM levels above the LOD of $212 \pm 112 \mathrm{pg} \mathrm{m}^{-3}$. The GEOS-Chem Hg model (version 9-02) with 237 bromine $(\mathrm{Br})$ chemistry was not able to reproduce the observed RM (simulated RM of $67 \pm 44 \mathrm{pg} \mathrm{m}^{-3}$ ), 238 suggesting either an underestimation of $\mathrm{Hg}(0)+\mathrm{Br}$ oxidation rates or $\mathrm{Br}$ concentration. The highest $\mathrm{RM}$ 239 concentrations, 300-680 $\mathrm{pg} \mathrm{m}^{-3}$, were observed in dry $(\mathrm{RH}<35 \%)$ and clean air masses during two flights over Texas at 5-7 km altitude and off the North Carolina coast at 1-3 km [10]. At the PDM we observed from 2012-2014 a total of $3602 \mathrm{~h}$ periods where $\mathrm{GOM}_{\mathrm{TK}} *$ levels were $>95^{\text {th }}$ percentile of all $\mathrm{GOM}_{\mathrm{TK}} *$ data. These high GOM* events are characteristic of free tropospheric air masses from various altitudes and had mean $\mathrm{GOM}_{\mathrm{TK}} *$ and $\mathrm{RM}_{\mathrm{TK}} *$ of $198 \pm 57$ and $229 \pm 58 \mathrm{pg} \mathrm{m}^{-3}$ which is very similar to the mean RM level of $212 \mathrm{pg} \mathrm{m}^{-3}$ observed during the 19 NOMADSS flights. From 2012-2014 the maximum $\mathrm{RM}_{\mathrm{TK}}{ }^{*}$ at PDM detected was 470 pg $\mathrm{m}^{-3}$, and $47 \mathrm{GOM}_{\mathrm{TK}} *$ events had $\mathrm{RM}>300 \mathrm{pg} \mathrm{m}^{-3}$ which is also within the range of highest RM during NOMADSS. A more in-depth analysis of NOMADSS RF-06 flight where TM, RM, GEM and BrO were simultaneously observed in the free troposphere over Texas resolved the model vs. observation RM mismatch [9]. BrO was quantified using airborne differential optical absorption spectroscopy (DOAS). GEOSChem correctly predicted the RM-rich air mass, yet underestimated the magnitude of the enhancement. Modeled BrO mixing ratios (0.40 pptv) were significantly lower than in situ BrO measurements (1.9 pptv), leading the authors to suggest that $\mathrm{Br}$ concentrations in GEOS-Chem are biased low, causing the underestimated RM levels [9]. However, substantial disagreement exists on BrO levels in the free troposphere where DOAS techniques yield 2-4 times higher BrO levels $(0.3$ to 3.4 pptv $[9,37])$ than those predicted (GEOS-Chem) or observed by chemical ionization mass spectrometry (CIMS, with nearly all tropospheric $\mathrm{BrO}<1$ pptv LOD [38]). More accurate observations of $\mathrm{BrO}$ are therefore just as essential as accurate RM measurements in our quest to understand atmospheric GEM oxidation pathways.

Weiss-Penzias et al. (2015) reviewed GEM and RM (calculated as GOM+PBM from Tekran ${ }^{\circledR}$ analyzers) observations from five high-elevation sites and compared them with the GEOS-Chem model (version 9-0101). RM levels in a free tropospheric subset of the data (identified as dry air with $<75^{\text {th }}$ percentile of water vapour levels at each site) show an annual mean of $34 \mathrm{pg} \mathrm{m}^{-3}$. The highest RM concentrations occurred 
261 during summertime dry air conditions at DRI, MBO and SPL (mean $61 \mathrm{pg} \mathrm{m}^{-3}$ ) sites, but not LABS (due to 262 humidity and high wet deposition). Non-bias corrected PDM observations for dry air (same $<75^{\text {th }}$ percentile 263 criterion) show similar annual and summertime mean $\mathrm{RM}_{\mathrm{TK}}$ levels of 51 and $44 \mathrm{pg} \mathrm{m}^{-3}$ respectively, and 264 maximum $\mathrm{RM}$ in spring $\left(63 \mathrm{pg} \mathrm{m}^{-3}\right)$. Annual mean modelled dry air RM of $84 \mathrm{~g} \mathrm{~m}^{-3}$ (Table SI-1 in ref. $\mathrm{X}$ ) at the 265 reviewed high-elevation sites over-predicted the reviewed observations, with annual mean RM of $34 \mathrm{pg} \mathrm{m}^{-3}$, 266 by a factor of 2.5 [8]. Annual mean, bias corrected, $\mathrm{RM}_{\mathrm{TK}}{ }^{*}$ in dry air at PDM is $58 \mathrm{pg} \mathrm{m}^{-3}$, which is still lower 267 than the modelled RM of $84 \mathrm{pg} \mathrm{m}^{-3}$, but only within a factor 1.5. It should be noted that dry air $\mathrm{RM}_{\mathrm{TK}}$ * 268 depends on the quartile used for water vapour screening [8], i.e. $\mathrm{RM}_{\mathrm{TK}}{ }^{*}$ is 58,66 and $80 \mathrm{pg} \mathrm{m}^{-3}$ for the $75^{\text {th }}$, $26950^{\text {th }}$ and $25^{\text {th }}$ percentile WV-screening cut-off, the latter being much more relevant for delimiting free tropospheric dry air at PDM. Therefore, based on our PDM observations, mountain-top RM observations by denuder methods, when corrected for $\mathrm{GOM}_{\mathrm{TK}}$ loss, would yield $\mathrm{RM}_{\mathrm{TK}}{ }^{*}$ levels that are closer to simulated $\mathrm{RM}$ by the GEOS-Chem model and regardless of $\mathrm{Br}$ oxidation or $\mathrm{OH}-\mathrm{O}_{3}$ oxidation schemes used.

In conclusion, we showed that automated $\mathrm{KCl}$-coated denuder based detection of GOM at the Pic du Midi can be corrected for GOM loss by including $\mathrm{Hg}$ detected during the instrument's flush cycles. Future research should further examine flush ${ }_{\mathrm{TK}}$ cycle behaviour and intercompare denuder-based GOM and PBM measurements with CEM based RM at a variety of sites, including but not limited to urban-industrial areas, remote terrestrial, marine boundary layer or polar sites. New studies should also attempt to understand which of the Tekran ${ }^{\circledR}$ inlet glass ware or the $\mathrm{KCl}$-coated denuder is the primary cause of $\mathrm{Hg}$ loss during the flush cycles, and if possible investigate technical solution to the problem. More accurate RM observations at mountain-tops should also stimulate continued testing of GEM oxidation schemes in atmospheric $\mathrm{Hg}$ 281 models.

\section{Acknowledgments}

284 This work was supported by research grant ERC-2010-StG_20091028 from the European Research Council to 285 JES. We warmly acknowledge technical support from the UMS 831 Pic du Midi observatory team. 


\section{Figure captions}

288 Figure 1a-f. Two-hourly (a) and bi-weekly (b-f) integrated relationships between automated Tekran ${ }^{\circledR} \mathrm{GOM}_{\mathrm{TK}}$, $289 \mathrm{PBM}_{\mathrm{TK}}, \mathrm{RM}_{\mathrm{TK}}$, flush $\mathrm{TK1-3}_{1}$ measurements and manual CEM observations of $\mathrm{RM}_{\mathrm{CEM}}$ at the Pic du Midi (all units in $290 \mathrm{pg} \mathrm{m}{ }^{-3}$ ). $\mathrm{RM}_{\mathrm{TK}}=\mathrm{GOM}_{\mathrm{TK}}+\mathrm{PBM}_{\mathrm{TK}} \mathrm{nd} \mathrm{GOM}_{\mathrm{CEM}}=\mathrm{RM}_{\mathrm{CEM}}-\mathrm{GOM}_{\mathrm{TK}}$ (see text for details). Linear regression lines in 291 panels c, d, e, f are forced through the origin, which has little effect on the $R^{2}$ values.

292

293 
294 Table 1. Summary of the 6-month CEM and Tekran ${ }^{\circledR}$ (TK) inter-comparison results at the Pic du Midi. St47 = 295 Sterlitech 47mm, and Mi90 = Millipore $90 \mathrm{~mm} \mathrm{CEMs.} \mathrm{PBMTK}$ and GOM TK $_{\text {are not corrected for } 3 \times \text { flush }}$ TK3 296 blank. GOM ${ }_{T K}$ loss corrected $\mathrm{RM}_{\mathrm{TK}} *=\mathrm{PBM}_{\mathrm{TK}}+\mathrm{GOM}_{\mathrm{TK}}+$ flush $_{\mathrm{TK} 1-3}$.

\begin{tabular}{|c|c|c|c|c|c|c|c|c|c|c|c|c|c|c|}
\hline Sample & Start & End & $\begin{array}{l}\mathrm{RH} \\
\%\end{array}$ & $\begin{array}{c}\text { O3 } \\
\text { ppbv }\end{array}$ & $\begin{array}{l}\text { CO } \\
\text { ppbv }\end{array}$ & $\begin{array}{l}\text { GEM }_{\text {TK }} \\
\mathrm{ng} \mathrm{m}^{-3}\end{array}$ & $\begin{array}{l}\mathrm{PBM}_{\mathrm{TK}} \\
\mathrm{pg} \mathrm{m}^{-3}\end{array}$ & $\begin{array}{l}\mathrm{GOM}_{\mathrm{T}} \\
\mathrm{pg} \mathrm{m}^{-3}\end{array}$ & $\begin{array}{l}\text { Flush }_{\text {TK1 }} \\
\mathrm{pg} \mathrm{m}^{-3}\end{array}$ & $\begin{array}{l}\text { Flush }_{\text {TK2 }} \\
\mathrm{pg} \mathrm{m}^{-3}\end{array}$ & $\begin{array}{l}\text { Flush }_{\text {TKз }} \\
\mathrm{pg} \mathrm{m}^{-3}\end{array}$ & $\begin{array}{l}\text { Flush }_{\text {TK1-3 }} \\
\mathrm{pg} \mathrm{m}^{-3}\end{array}$ & $\begin{array}{l}\mathrm{RM}_{\mathrm{TK}}{ }^{*} \\
\mathrm{pg} \mathrm{m}^{-3}\end{array}$ & $\begin{array}{l}\mathrm{RM}_{\mathrm{CEM}} \\
\mathrm{pg} \mathrm{m}^{-3}\end{array}$ \\
\hline 1-St47 & $18 / 6 / 14$ & $4 / 7 / 14$ & 84 & 52 & 80 & 1.40 & 20.8 & 14.7 & 4.3 & 1.2 & 0.3 & 5.8 & 41 & 43 \\
\hline 2-St47 & $17 / 7 / 14$ & $4 / 8 / 14$ & 76 & 51 & 84 & 1.45 & 28.6 & 25.1 & 8.9 & 2.1 & 0.5 & 11.6 & 65 & 72 \\
\hline $3-S t 47$ & $4 / 8 / 14$ & $26 / 8 / 14$ & 76 & 47 & 94 & 1.50 & 41.5 & 22.0 & 6.2 & 1.6 & 0.3 & 8.1 & 100 & 120 \\
\hline 4-St90 & $14 / 7 / 14$ & $17 / 7 / 14$ & 54 & 48 & 76 & 1.54 & 28.6 & 48.5 & 19.1 & 3.2 & 0.8 & 23.2 & 100 & 86 \\
\hline $5-S t 90$ & $14 / 7 / 14$ & $17 / 7 / 14$ & 54 & 48 & 76 & 1.54 & 28.6 & 48.5 & 19.1 & 3.2 & 0.8 & 23.2 & 72 & 71 \\
\hline $6-S t 47$ & $29 / 9 / 14$ & $16 / 10 / 1$ & 88 & 40 & 75 & 1.59 & 33.6 & 12.6 & 4.2 & 0.7 & 0.1 & 5.0 & 51 & 57 \\
\hline 7-St90 & $29 / 9 / 14$ & $16 / 10 / 1$ & 88 & 40 & 75 & 1.59 & 33.6 & 12.6 & 4.2 & 0.7 & 0.1 & 5.0 & 51 & 47 \\
\hline $8-S t 47$ & $16 / 10 / 1$ & $6 / 11 / 14$ & 66 & 38 & 68 & 1.53 & 10.9 & 28.7 & 17.2 & 1.6 & 0.3 & 19.1 & 59 & 57 \\
\hline 9-Мi90 & $6 / 11 / 14$ & $20 / 11 / 1$ & 84 & 42 & 89 & 1.43 & 13.1 & 7.0 & 7.2 & 1.4 & 0.4 & 9.0 & 29 & 39 \\
\hline 10-Mi47 & $6 / 11 / 14$ & $20 / 11 / 1$ & 84 & 42 & 89 & 1.43 & 13.1 & 7.0 & 7.3 & 1.4 & 0.4 & 9.0 & 29 & 34 \\
\hline 11-Mi90 & $1 / 12 / 14$ & $2 / 12 / 14$ & 95 & 39 & 104 & 1.62 & 15.3 & 20.9 & 5.5 & 0.7 & 0.3 & 6.5 & 43 & 50 \\
\hline 12-Мi90 & $2 / 12 / 14$ & $3 / 12 / 14$ & 95 & 43 & 78 & 1.43 & 23.9 & 31.5 & 12.9 & 2.1 & 0.5 & 15.5 & 71 & 75 \\
\hline 13-Мi90 & $3 / 12 / 14$ & $4 / 12 / 14$ & 95 & 44 & 79 & 1.40 & 20.6 & 41.1 & 21.5 & 1.8 & 1.0 & 24.4 & 86 & 84 \\
\hline 14-Mi90 & $4 / 12 / 14$ & $5 / 12 / 14$ & 95 & 35 & 126 & 1.75 & 9.8 & 3.1 & 1.0 & 0.0 & 0.0 & 1.0 & 14 & 19 \\
\hline 15-Мi90 & $5 / 12 / 14$ & $6 / 12 / 14$ & 94 & 32 & 138 & 1.68 & 8.9 & 2.0 & 1.2 & 0.0 & 0.0 & 1.2 & 12 & 11 \\
\hline 16-Мi90 & $6 / 12 / 14$ & $22 / 12 / 1$ & 74 & 43 & 92 & 1.38 & 35.6 & 10.3 & 4.7 & 1.2 & 1.1 & 7.1 & 53 & 41 \\
\hline 17-Mi47 & $5 / 12 / 14$ & $22 / 12 / 1$ & 75 & 42 & 94 & 1.39 & 34.7 & 10.0 & 4.6 & 1.2 & 1.1 & 6.9 & 52 & 53 \\
\hline 18-Mi47 & $5 / 12 / 14$ & $22 / 12 / 1$ & 75 & 42 & 94 & 1.39 & 34.7 & 10.0 & 4.6 & 1.2 & 1.1 & 6.9 & 52 & 43 \\
\hline
\end{tabular}


298 Table 2. Illustration of Hg loss during the flush cycles (in bold) of the automated Tekran ${ }^{\circledR} 1130 / 1135 / 2537 \mathrm{~B}$

299 system for two typical high GOM and high PBM events at the PDM discussed by Fu et al., 2016. For both

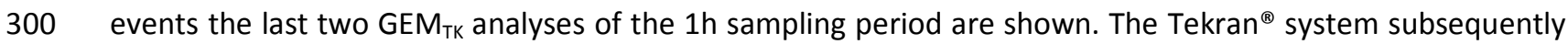

301 enters its 1 desorption period consisting of 3 flush cycles, pyrolizer heating cycle, 3 RPF heating cycles to

302 quantify $\mathrm{PBM}_{\mathrm{TK}}, 3$ denuder heating cycles to quantify $\mathrm{GOM}_{\mathrm{TK}}$, and two additional flush cycles. Flush blanks

303 correlate with $\mathrm{GOM}_{\mathrm{TK}}$ levels, but not with $\mathrm{PBM}_{\mathrm{TK}}$ suggesting continuous GOM loss from KCl-coated denuders 304 and/or inlet system.

305

\begin{tabular}{|c|c|c|c|}
\hline \multicolumn{4}{|c|}{ High GOM event \#7 - 16/05/2012 } \\
\hline Local Time & Cycle Type & Peak Area & $\begin{array}{c}\mathrm{GEM} \\
\mathrm{ng} \mathrm{m}^{-3}\end{array}$ \\
\hline 05:25 & GEM & 26867 & 1.47 \\
\hline 05:30 & GEM & 26467 & 1.52 \\
\hline 05:35 & flush 1 & 52592 & \\
\hline 05:40 & flush 2 & 38508 & \\
\hline 05:45 & flush 3 & 21263 & \\
\hline 05:50 & Pyrolizer & 16294 & \\
\hline 05:55 & PBM 1 & 194972 & \\
\hline 06:00 & PBM 2 & 11660 & \\
\hline 06:05 & PBM 3 & 4770 & \\
\hline $06: 10$ & GOM 1 & 302458 & \\
\hline $06: 15$ & GOM 2 & 7553 & \\
\hline $06: 20$ & GOM 3 & 3651 & \\
\hline $06: 25$ & flush 4 & 0 & \\
\hline 06:30 & flush 5 & 0 & \\
\hline
\end{tabular}

\begin{tabular}{cccccc}
$\begin{array}{c}\text { GOM/PBM /flush } \\
\text { Hg m }\end{array}$ & $\begin{array}{c}\text { High PBM event \#12 - 21/02/2012 } \\
\text { Local Time }\end{array}$ & Flag & Peak Area & \multicolumn{2}{c}{ GEM GOM/PBM /flush } \\
& & & & $\mathrm{ng} \mathrm{m}^{-3}$ & $\mathrm{pg} \mathrm{m}^{-3}$ \\
& $07: 20$ & GEM & 28321 & 1.69 & \\
$\mathbf{2 6 . 8}$ & $07: 25$ & GEM & 26960 & 1.68 & \\
$\mathbf{2 0 . 7}$ & $07: 30$ & flush 1 & 5704 & & $\mathbf{3 . 2}$ \\
$\mathbf{1 0 . 8}$ & $07: 35$ & flush 2 & 3240 & $\mathbf{1 . 9}$ \\
8.8 & $07: 40$ & flush 3 & 0 & 0 \\
99.3 & $07: 45$ & Pyrolizer & 12242 & 7.1 \\
6.3 & $07: 50$ & PBM 1 & 143855 & 80.3 \\
2.4 & $07: 55$ & PBM 2 & 18719 & 10.9 \\
162.5 & $08: 00$ & PBM 3 & 4062 & 2.3 \\
3.8 & $08: 05$ & GOM 1 & 45615 & 26.5 \\
2.0 & $08: 10$ & GOM 2 & 1385 & 0.8 \\
0 & $08: 15$ & GOM 3 & 0 & 0 \\
0 & $08: 20$ & flush 4 & 0 & 0 \\
& $08: 25$ & flush 5 & 0 & 0
\end{tabular}


309 Figure 1a-f. Two-hourly (a) and bi-weekly (b-f) integrated relationships between automated Tekran ${ }^{\circledR} \mathrm{GOM}_{\mathrm{TK}}$,

$310 \mathrm{PBM}_{\mathrm{TK}}, \mathrm{RM}_{\mathrm{TK}}$, and flush $\mathrm{TK1}_{-3}$ measurements and manual CEM observations of $\mathrm{RM}_{\mathrm{CEM}}$ at the Pic du Midi (all

311 units in $\mathrm{pg} \mathrm{m}{ }^{-3}$ ). $\mathrm{RM}_{\mathrm{TK}}=\mathrm{GOM}_{\mathrm{TK}}+\mathrm{PBM}_{\mathrm{TK}}$ and $\mathrm{GOM}_{\mathrm{CEM}}=\mathrm{RM}_{\mathrm{CEM}}-\mathrm{GOM}_{\mathrm{TK}}$ (see text for details). Linear regression

312 lines in panels $c, d, e, f$ are forced through the origin, which has little effect on the $R^{2}$ values.
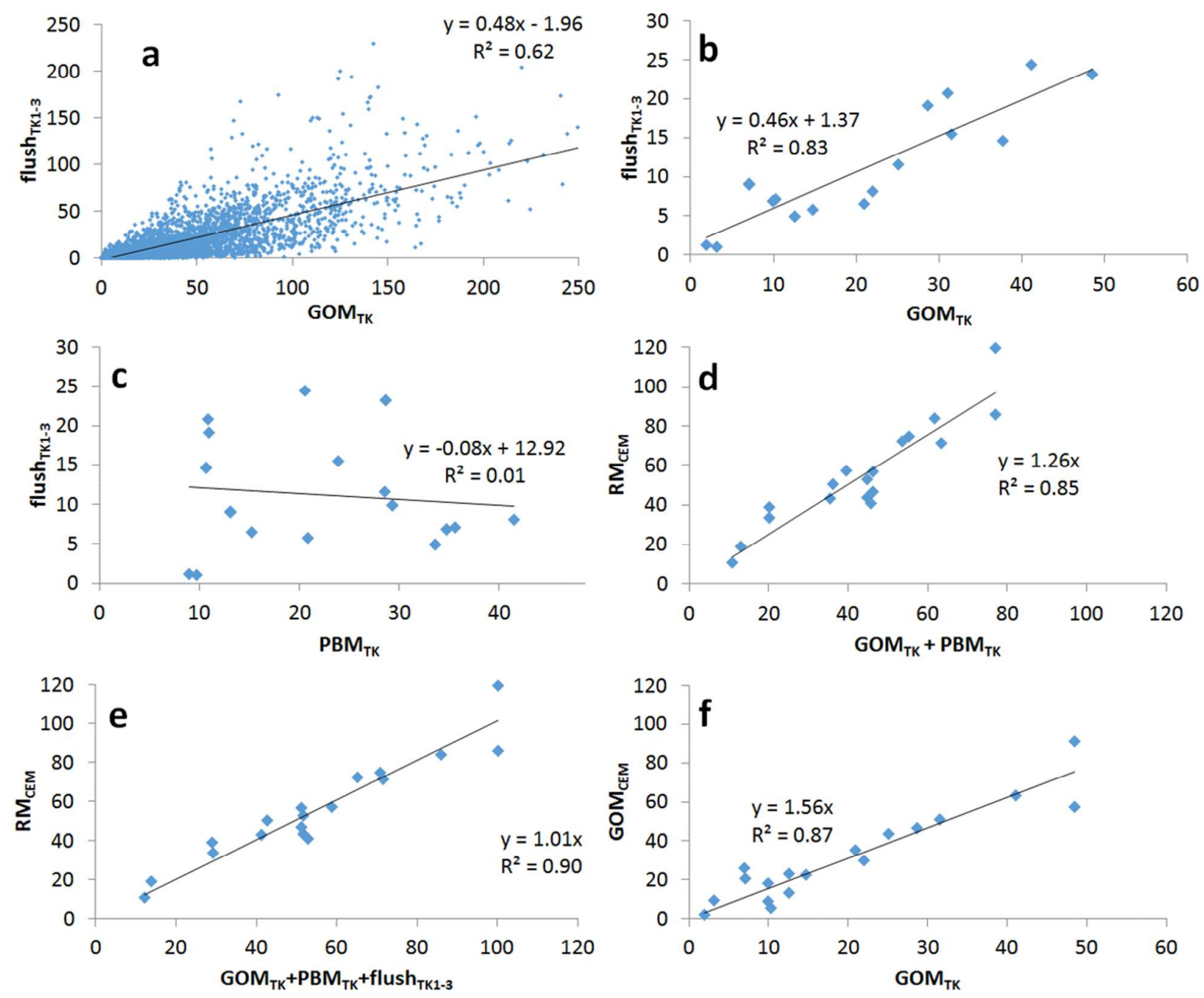

313 


\section{References}

1. Amos, H. M.; Sonke, J. E.; Obrist, D.; Robins, N.; Hagan, N.; Horowitz, H. M.; Mason, R. P.; Witt, M.; Hedgecock, I. M.; Corbitt, E. S.; Sunderland, E. M., Observational and Modeling Constraints on Global Anthropogenic Enrichment of Mercury. Environmental Science \& Technology 2015, 49, (7), 4036-4047.

2. UNEP, Global Mercury Assessment 2013: Sources, Emissions, Releases and Environmental Transport. UNEP Chemicals Branch, Geneva, Switzerland. 2013.

3. Enrico, M.; Le Roux, G.; Marusczak, N.; Heimbürger, L.-E.; Claustres, A.; Fu, X.; Sun, R.; Sonke, J. E., Atmospheric mercury transfer to peat bogs dominated by gaseous elemental mercury dry deposition. Environmental Science \& Technology 2016.

4. Parrella, J. P.; Jacob, D. J.; Liang, Q.; Zhang, Y.; Mickley, L. J.; Miller, B.; Evans, M. J.; Yang, X.; Pyle, J. A.; Theys, N.; Van Roozendael, M., Tropospheric bromine chemistry: implications for present and preindustrial ozone and mercury. Atmospheric Chemistry and Physics 2012, 12, (15), 6723-6740.

5. Amos, H. M.; Jacob, D. J.; Holmes, C. D.; Fisher, J. A.; Wang, Q.; Yantosca, R. M.; Corbitt, E. S.; Galarneau, E.; Rutter, A. P.; Gustin, M. S.; Steffen, A.; Schauer, J. J.; Graydon, J. A.; St Louis, V. L.; Talbot, R. W.; Edgerton, E. S.; Zhang, Y.; Sunderland, E. M., Gas-particle partitioning of atmospheric $\mathrm{Hg}(\mathrm{II})$ and its effect on global mercury deposition. Atmospheric Chemistry and Physics 2012, 12, (1), 591-603.

6. Seigneur, C.; Vijayaraghavan, K.; Lohman, K., Atmospheric mercury chemistry: Sensitivity of global model simulations to chemical reactions. Journal of Geophysical Research-Atmosphere 2006, 111, D22306.

7. Holmes, C. D.; Jacob, D. J.; Corbitt, E. S.; Mao, J.; Yang, X.; Talbot, R.; Slemr, F., Global atmospheric model for mercury including oxidation by bromine atoms. Atmospheric Chemistry and Physics 2010, 10, 12037-12057.

8. Weiss-Penzias, P.; Amos, H. M.; Selin, N. E.; Gustin, M. S.; Jaffe, D. A.; Obrist, D.; Sheu, G. R.; Giang, A., Use of a global model to understand speciated atmospheric mercury observations at five high-elevation sites. Atmospheric Chemistry and Physics 2015, 15, (3), 1161-1173.

9. Gratz, L. E.; Ambrose, J. L.; Jaffe, D. A.; Shah, V.; Jaegle, L.; Stutz, J.; Festa, J.; Spolaor, M.; Tsai, C.; Selin, N. E.; Song, S.; Zhou, X.; Weinheimer, A. J.; Knapp, D. J.; Montzka, D. D.; Flocke, F. M.; Campos, T. L.; Apel, E.; Hornbrook, R.; Blake, N. J.; Hall, S.; Tyndall, G. S.; Reeves, M.; Stechman, D.; Stell, M., Oxidation of mercury by bromine in the subtropical Pacific free troposphere. Geophysical Research Letters 2015, 42, (23).

10. Shah, V.; Jaegle, L.; Gratz, L. E.; Ambrose, J. L.; Jaffe, D. A.; Selin, N. E.; Song, S.; Campos, T. L.; Flocke, F. M.; Reeves, M.; Stechman, D.; Stell, M.; Festa, J.; Stutz, J.; Weinheimer, A. J.; Knapp, D. J.; Montzka, D. D.; Tyndall, G. S.; Apel, E. C.; Hornbrook, R. S.; Hills, A. J.; Riemer, D. D.; Blake, N. J.; Cantrell, C. A.; Mauldin, R. L., Origin of oxidized mercury in the summertime free troposphere over the southeastern US. Atmospheric Chemistry and Physics 2016, 16, (3), 1511-1530.

11. Laudal, D.; Nott, B.; Brown, T.; Roberson, R., Mercury speciation methods for utility flue gas. Fresenius Journal of Analytical Chemistry 1997, 358, (3), 397-400.

12. Stratton, W. J.; Lindberg, S. E., Use of a refluxing mist chamber for measurement of gas-phase mercury(II) species in the atmosphere. Water Air and Soil Pollution 1995, 80, (1-4), 1269-1278.

13. Landis, M. S.; Stevens, R. K.; Schaedlich, F.; Prestbo, E., Development and Characterization of an Annular Denuder Methodology for the Measurement of Divalent Inorganic Reactive Gaseous Mercury in Ambient Air. Environmental Science and Technology 2002, 36, 3000-3009.

14. Xiao, Z.; Sommar, J.; Wei, S.; Lindqvist, O., Sampling and determination of gas phase divalent mercury in the air using a $\mathrm{KCl}$ coated denuder. Fresenius Journal of Analytical Chemistry 1997, 358, (3), 386391.

15. Lyman, S. N.; Gustin, M. S.; Prestbo, E. M.; Marsik, F. J., Estimation of dry deposition of atmospheric mercury in Nevada by direct and indirect methods. Environmental Science \& Technology 2007, 41, (6), 19701976.

16. Huang, J.; Miller, M. B.; Weiss-Penzias, P.; Gustin, M. S., Comparison of Gaseous Oxidized Hg Measured by $\mathrm{KCl}-$ Coated Denuders, and Nylon and Cation Exchange Membranes. Environmental Science \& Technology 2013, 47, (13), 7307-7316. 
17. Bloom, N. S.; Prestbo, E. M.; Von der Geest, E. In Determination of atmospheric gaseous Hg(II) at the $\mathrm{pg} / \mathrm{m} 3$ level by collection onto cation exchange membranes, followed by dual amalgamation/cold caport atomic fluorescence spectrometry, 4th International Conference on Mercury as a Global Pollutant, Hamburg, 1996; Ebinghaus, R.; Petersen, G.; Tumpling, U., Eds. GKKS: Hamburg, 1996; p 190.

18. Swartzendruber, P. C.; Jaffe, D. A.; Finley, B., Development and First Results of an Aircraft-Based, High Time Resolution Technique for Gaseous Elemental and Reactive (Oxidized) Gaseous Mercury. Environmental Science \& Technology 2009, 43, (19), 7484-7489.

19. Ambrose, J. L.; Gratz, L. E.; Jaffe, D. A.; Campos, T.; Flocke, F. M.; Knapp, D. J.; Stechman, D. M.; Stell, M.; Weinheimer, A. J.; Cantrell, C. A.; Mauldin, R. L., Mercury Emission Ratios from Coal-Fired Power Plants in the Southeastern United States during NOMADSS. Environmental Science \& Technology 2015, 49, (17), 10389-10397.

20. Lyman, S. N.; Jaffe, D. A., Formation and fate of oxidized mercury in the upper troposphere and lower stratosphere. Nature Geoscience 2011, 5, (2), 114-117.

21. Deeds, D. A.; Ghoshdastidar, A.; Raofie, F.; Guerette, E. A.; Tessier, A.; Ariya, P. A., Development of a Particle-Trap Preconcentration-Soft Ionization Mass Spectrometric Technique for the Quantification of Mercury Halides in Air. Analytical Chemistry 2015, 87, (10), 5109-5116.

22. Lan, X.; Talbot, R.; Castro, M.; Perry, K.; Luke, W., Seasonal and diurnal variations of atmospheric mercury across the US determined from AMNet monitoring data. Atmospheric Chemistry and Physics 2012, 12, (21), 10569-10582.

23. Sprovieri, F.; Gratz, L. E.; Pirrone, N., Development of a Ground-Based Atmospheric Monitoring Network for the Global Mercury Observation System (GMOS). In Proceedings of the 16th International Conference on Heavy Metals in the Environment, Pirrone, N., Ed. 2013; Vol. 1.

24. Cole, A. S.; Steffen, A.; Eckley, C. S.; Narayan, J.; Pilote, M.; Tordon, R.; Graydon, J. A.; St Louis, V. L.; $\mathrm{Xu}, \mathrm{X}$. H.; Branfireun, B. A., A Survey of Mercury in Air and Precipitation across Canada: Patterns and Trends. Atmosphere 2014, 5, (3), 635-668.

25. Lyman, S. N.; Jaffe, D. A.; Gustin, M. S., Release of mercury halides from $\mathrm{KCl}$ denuders in the presence of ozone. Atmospheric Chemistry and Physics 2010, 10, (17), 8197-8204.

26. Gustin, M. S.; Huang, J.; Miller, M. B.; Peterson, C.; Jaffe, D. A.; Ambrose, J.; Finley, B. D.; Lyman, S. N.; Call, K.; Talbot, R.; Feddersen, D.; Mao, H.; Lindberg, S. E., Do We Understand What the Mercury Speciation Instruments Are Actually Measuring? Results of RAMIX. Environmental Science and Technology 2013, DOI: 10.1021/es3039104.

27. McClure, C. D.; Jaffe, D. A.; Edgerton, E. S., Evaluation of the $\mathrm{KCl}$ Denuder Method for Gaseous Oxidized Mercury using $\mathrm{HgBr} 2$ at an In-Service AMNet Site. Environmental Science \& Technology 2014, 48, (19), 11437-11444.

28. Huang, J. Y.; Gustin, M. S., Uncertainties of Gaseous Oxidized Mercury Measurements Using KClCoated Denuders, Cation-Exchange Membranes, and Nylon Membranes: Humidity Influences. Environmental Science \& Technology 2015, 49, (10), 6102-6108.

29. Ambrose, J. L.; Lyman, S. N.; Huang, J.; Gustin, M. S.; Jaffe, D. A., Fast Time Resolution Oxidized Mercury Measurements during the Reno Atmospheric Mercury Intercomparison Experiment (RAMIX). Environmental Science \& Technology 2013, 47, (13), 7285-7294.

30. Gustin, M. S.; Huang, J. Y.; Miller, M. B.; Peterson, C.; Jaffe, D. A.; Ambrose, J.; Finley, B. D.; Lyman, S. N.; Call, K.; Talbot, R.; Feddersen, D.; Mao, H. T.; Lindberg, S. E., Do We Understand What the Mercury Speciation Instruments Are Actually Measuring? Results of RAMIX. Environmental Science \& Technology 2013, 47, (13), 7295-7306.

31. Jaffe, D. A.; Lyman, S.; Amos, H. M.; Gustin, M. S.; Huang, J.; Selin, N. E.; Levin, L.; ter Schure, A.; Mason, R. P.; Talbot, R.; Rutter, A.; Finley, B.; Jaegle, L.; Shah, V.; McClure, C.; Arnbrose, J.; Gratz, L.; Lindberg, S.; Weiss-Penzias, P.; Sheu, G.-R.; Feddersen, D.; Horvat, M.; Dastoor, A.; Hynes, A. J.; Mao, H.; Sonke, J. E.; Slemr, F.; Fisher, J. A.; Ebinghaus, R.; Zhang, Y.; Edwards, G., Progress on Understanding Atmospheric Mercury Hampered by Uncertain Measurements. Environmental Science \& Technology 2014, $48,(13), 7204-7206$. 
$415 \quad$ 32. Gheusi, F.; Ravetta, F.; Delbarre, H.; Tsamalis, C.; Chevalier-Rosso, A.; Leroy, C.; Augustin, P.; Delmas, 416 R.; Ancellet, G.; Athier, G.; Bouchou, P.; Campistron, B.; Cousin, J. M.; Fourmentin, M.; Meyerfeld, Y., Pic 417 2005, a field campaign to investigate low-tropospheric ozone variability in the Pyrenees. Atmospheric 418 Research 2011, 101, (3), 640-665.

419 33. Fu, X. W.; Marusczak, N.; Heimbürger, L. E.; Sauvage, B.; Gheusi, F.; Sonke, J. E., Atmospheric 420 mercury speciation dynamics at the high-altitude Pic du Midi Observatory, southern France. Atmospheric 421 Chemistry and Physics 2016, 16, 5623-5639.

422 34. PAES Atmospheric Pollution at the Synpotic Scale network. http://paes.aero.obs-mip.fr/ accessed in 4232016.

424 35. Finley, B. D.; Jaffe, D. A.; Call, K.; Lyman, S.; Gustin, M. S.; Peterson, C.; Miller, M.; Lyman, T., 425 Development, Testing, And Deployment of an Air Sampling Manifold for Spiking Elemental and Oxidized 426 Mercury During the Reno Atmospheric Mercury Intercomparison Experiment (RAMIX). Environmental 427 Science \& Technology 2013, 47, (13), 7277-7284.

$428 \quad 36 . \quad$ Brooks, S.; Ren, X. R.; Cohen, M.; Luke, W. T.; Kelley, P.; Artz, R.; Hynes, A.; Landing, W.; Martos, B., 429 Airborne Vertical Profiling of Mercury Speciation near Tullahoma, TN, USA. Atmosphere 2014, 5, (3), 557430574.

$431 \quad$ 37. Wang, S. Y.; Schmidt, J. A.; Baidar, S.; Coburn, S.; Dix, B.; Koenig, T. K.; Apel, E.; Bowdalo, D.; Campos, 432 T. L.; Eloranta, E.; Evans, M. J.; DiGangi, J. P.; Zondlo, M. A.; Gao, R. S.; Haggerty, J. A.; Hall, S. R.; Hornbrook, 433 R. S.; Jacob, D.; Morley, B.; Pierce, B.; Reeves, M.; Romashkin, P.; ter Schure, A.; Volkamer, R., Active and 434 widespread halogen chemistry in the tropical and subtropical free troposphere. Proceedings of the National 435 Academy of Sciences of the United States of America 2015, 112, (30), 9281-9286.

38. Chen, D.; Huey, D.; Tanner, D. J.; Salawitch, R. J.; Anderson, D. C.; Wales, P. A.; Pan, L. L.; Atlas, E. L.; Hornbrook, R. S.; Apel, E. C.; Blake, N. J.; Campos, T. L.; Donets, V.; Flocke, F. M.; Hall, S. R.; Hanisco, T. F.; Hills, A. J.; Honomichl, S. B.; Jensen, J. B.; Kaser, L.; Montzka, D. D.; Nicely, J. M.; Reeves, J. M.; Riemer, D. D.; Schauffler, S. M.; Ullmann, K.; Weinheimer, A. J.; Wolfe, G. M., Airborne measurements of BrO and the sum 439

440 of $\mathrm{HOBr}$ and $\mathrm{Br} 2$ over the Tropical West Pacific from 1 to $15 \mathrm{~km}$ during the CONvective TRansport of Active 441 Species in the Tropics (CONTRAST) experiment. Journal of Geophysical Research 2016, 121, 12,560-12,578. 

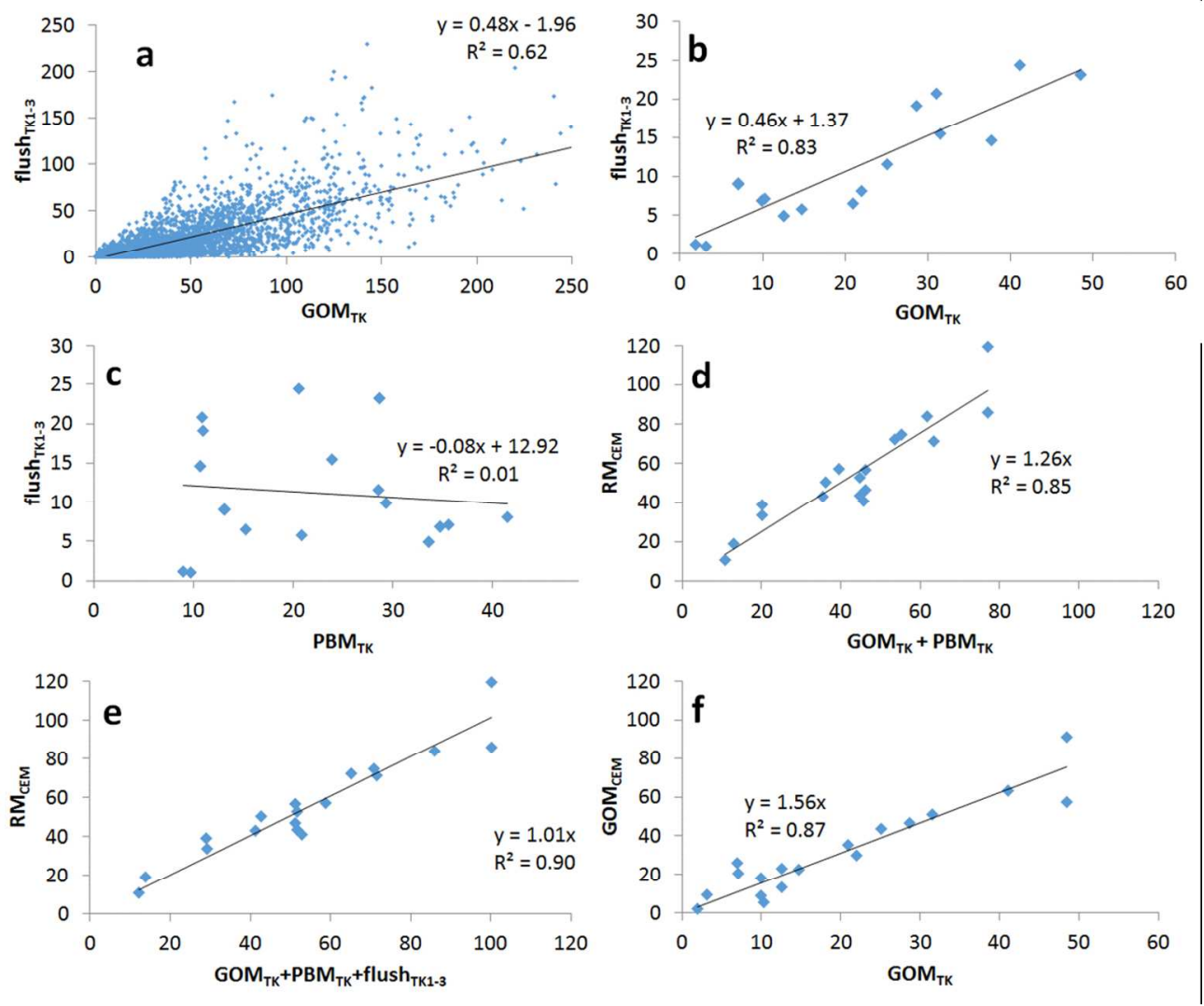

Figure 1a-f. Two-hourly (a) and bi-weekly (b-f) integrated relationships between automated Tekran ${ }^{\circledR}$ GOMTK, PBMTK, RMTK, and flushTK1-3 measurements and manual CEM observations of RMCEM at the Pic du Midi (all units in pg m-3). RMTK = GOMTK + PBMTK and GOMCEM = RMCEM - GOMTK (see text for details). Linear regression lines in panels $c, d, e, f$ are forced through the origin, which has little effect on the $\mathrm{R} 2$ values.

$220 \times 182 \mathrm{~mm}(150 \times 150 \mathrm{DPI})$ 


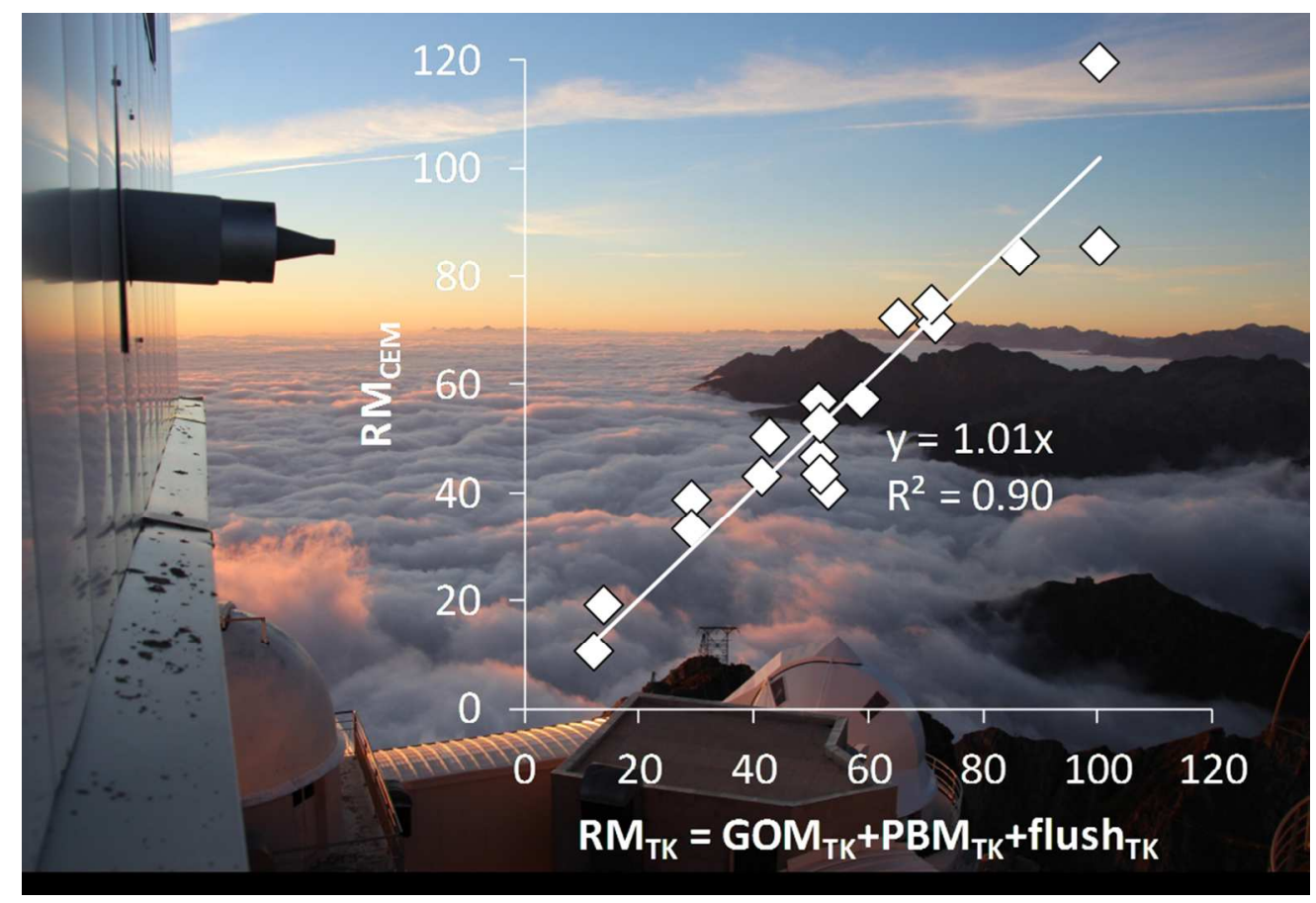

$185 \times 127 \mathrm{~mm}(150 \times 150 \mathrm{DPI})$ 